University of Nebraska - Lincoln DigitalCommons@University of Nebraska - Lincoln

Effects of Management Practices on Grassland Birds

US Geological Survey

$2-2004$

EFFECTS OF MANAGEMENT PRACTICES ON GRASSLAND BIRDS: MERLIN

Paul M. Konrad

Follow this and additional works at: http:// digitalcommons.unl.edu/empgb

Part of the Ornithology Commons, Plant Sciences Commons, and the Terrestrial and Aquatic Ecology Commons

This Article is brought to you for free and open access by the US Geological Survey at DigitalCommons@University of Nebraska - Lincoln. It has been accepted for inclusion in Effects of Management Practices on Grassland Birds by an authorized administrator of DigitalCommons@University of Nebraska - Lincoln. 


\section{EFFECTS OF MANAGEMENT PRACTICES ON GRASSLAND BIRDS:

\author{
MERLIN
}

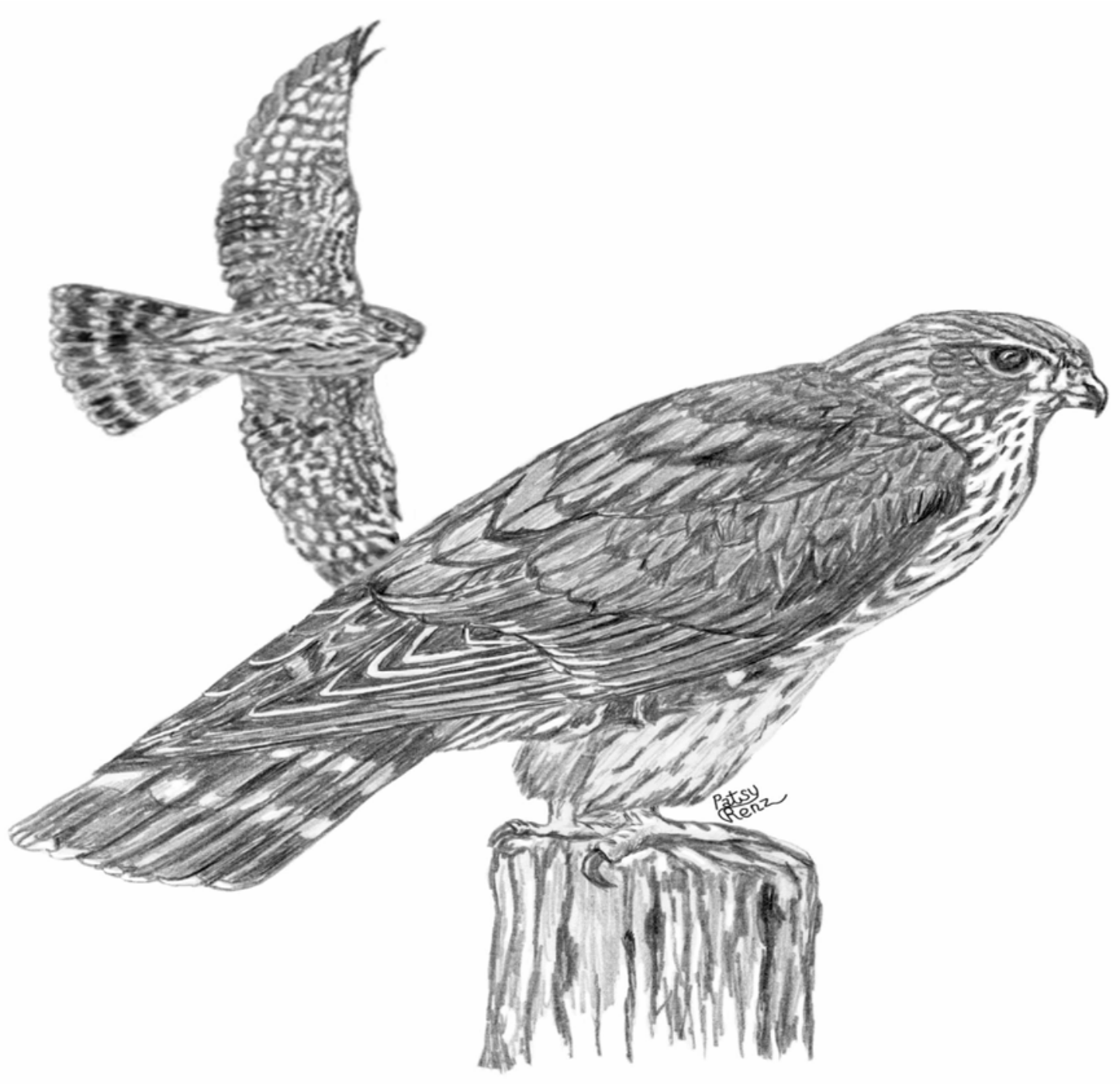

Grasslands Ecosystem Initiative

Northern Prairie Wildlife Research Center

U.S. Geological Survey

Jamestown, North Dakota 58401 
This report is one in a series of literature syntheses on North American grassland birds. The need for these reports was identified by the Prairie Pothole Joint Venture (PPJV), a part of the North American Waterfowl Management Plan. The PPJV adopted a goal to stabilize or increase populations of declining grasslandand wetland-associated wildlife species in the Prairie Pothole Region. To further that objective, it is essential to understand the habitat needs of birds other than waterfowl, and how management practices affect their habitats. The focus of these reports is on management of breeding habitat, particularly in the northern Great Plains.

Suggested citation:

Konrad, P. M. 2004. Effects of management practices on grassland birds: Merlin. Northern Prairie Wildlife Research Center, Jamestown, ND. 20 pages.

Species for which syntheses are available:

American Bittern

Mountain Plover

Marbled Godwit

Long-billed Curlew

Willet

Wilson's Phalarope

Upland Sandpiper

Greater Prairie-Chicken

Lesser Prairie-Chicken

Greater Sage-Grouse

Northern Harrier

Swainson's Hawk

Ferruginous Hawk

Golden Eagle

Prairie Falcon

Merlin

Short-eared Owl

Burrowing Owl

Horned Lark

Sedge Wren

Loggerhead Shrike

Sprague’s Pipit

Grasshopper Sparrow

Baird's Sparrow

Henslow's Sparrow

Le Conte's Sparrow

Nelson's Sharp-tailed Sparrow

Vesper Sparrow

Savannah Sparrow

Lark Sparrow

Field Sparrow

Brewer's Sparrow

Clay-colored Sparrow

Chestnut-collared Longspur

McCown's Longspur

Dickcissel

Lark Bunting

Bobolink

Eastern Meadowlark

Western Meadowlark

Brown-headed Cowbird 


\title{
EFFECTS OF MANAGEMENT PRACTICES ON GRASSLAND BIRDS:
}

\section{MERLIN}

\author{
Paul M. Konrad \\ Series Coordinator: Douglas H. Johnson \\ Series Assistant Coordinator: Lawrence D. Igl, Jill A. Dechant Shaffer \\ Reviewer: Ian G. Warkentin \\ Range Map: Sodhi et al. (1993) \\ Cover Art: Patsy Renz \\ Major Funding: U.S. Forest Service \\ Prairie Pothole Joint Venture, U.S. Fish and Wildlife Service \\ U.S. Geological Survey
}

February 2004 


\section{ORGANIZATION AND FEATURES OF THIS SPECIES ACCOUNT}

Information on the habitat requirements and effects of habitat management on grassland birds were summarized from information in more than 5,500 published and unpublished papers. A range map is provided to indicate the breeding, year-round, and nonbreeding ranges in the United States and southern Canada. Although birds frequently are observed outside the breeding range indicated, the maps are intended to show areas where managers might concentrate their attention. It may be ineffectual to manage habitat at a site for a species that rarely occurs in an area. The species account begins with a brief capsule statement, which provides the fundamental components or keys to management for the species. A section on breeding range outlines the current breeding distribution of the species in North America. The suitable habitat section describes the breeding habitat and occasionally microhabitat characteristics of the species, especially those habitats that occur in the Great Plains. Details on habitat and microhabitat requirements often provide clues to how a species will respond to a particular management practice. A table near the end of the account complements the section on suitable habitat, and lists the specific habitat characteristics for the species by individual studies. A special section on prey habitat is included for those predatory species that have more specific prey requirements. The area requirements section provides details on territory and home range sizes, minimum area requirements, and the effects of patch size, edges, and other landscape and habitat features on abundance and productivity. It may be futile to manage a small block of suitable habitat for a species that has minimum area requirements that are larger than the area being managed. The Brown-headed Cowbird (Molothrus ater) is an obligate brood parasite of many grassland birds. The section on cowbird brood parasitism summarizes rates of cowbird parasitism, host responses to parasitism, and factors that influence parasitism, such as nest concealment and host density. The impact of management depends, in part, upon a species' nesting phenology and biology. The section on breeding-season phenology and site fidelity includes details on spring arrival and fall departure for migratory populations in the Great Plains, peak breeding periods, the tendency to renest after nest failure or success, and the propensity to return to a previous breeding site. The duration and timing of breeding varies among regions and years. Species' response to management summarizes the current knowledge and major findings in the literature on the effects of different management practices on the species. The section on management recommendations complements the previous section and summarizes specific recommendations for habitat management provided in the literature. If management recommendations differ in different portions of the species' breeding range, recommendations are given separately by region. The literature cited contains references to published and unpublished literature on the management effects and habitat requirements of the species. This section is not meant to be a complete bibliography; a searchable, annotated bibliography of published and unpublished papers dealing with habitat needs of grassland birds and their responses to habitat management is posted at the Web site mentioned below.

This report has been downloaded from the Northern Prairie Wildlife Research Center World-Wide Web site, www.npwrc.usgs.gov/resource/literatr/grasbird/grasbird.htm. Please direct comments and suggestions to Douglas H. Johnson, Northern Prairie Wildlife Research Center, U.S. Geological Survey, 8711 37th Street SE, Jamestown, North Dakota 58401; telephone: 701-253-5539; fax: 701-253-5553; email: Douglas_H_Johnson@usgs.gov. 


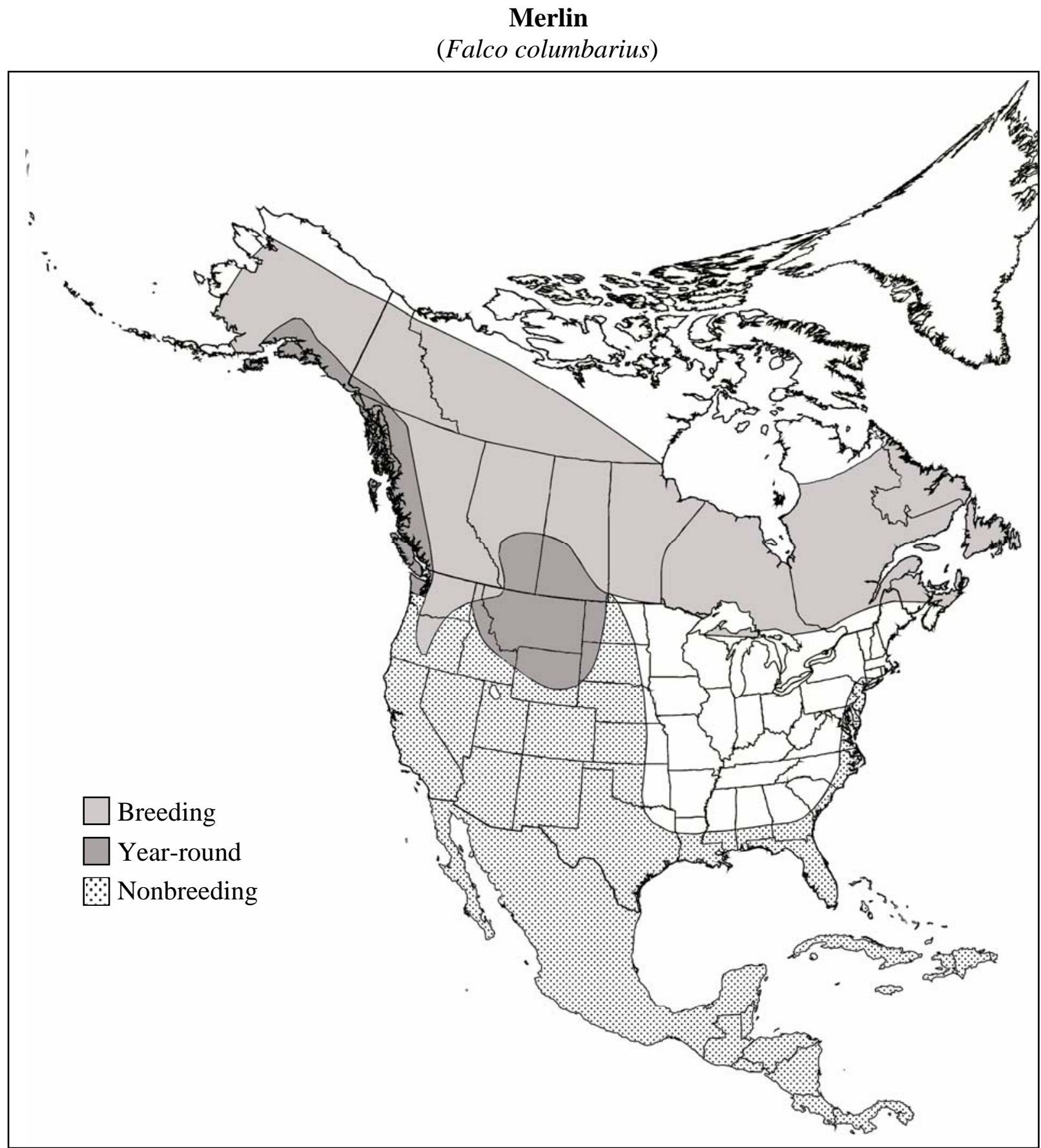

Figure. Distribution of Merlin in North America. Map adapted from Sodhi et al. (1993), used with permission of the authors.

Key to management is maintaining an interspersion of open grasslands for hunting with groves of deciduous or coniferous trees for nesting. Optimal habitat is in rural areas at least $400 \mathrm{~m}$ from human disturbance.

\section{Breeding range:}

Merlins breed from the northern limits of the tree line from northern Alaska to northern 
Newfoundland and Labrador south throughout most of Canada (except the northeastern Northwest Territories and northern Quebec) as well as western Washington, Idaho, Montana, Wyoming, North Dakota, South Dakota, and northern Maine (National Geographic Society 1999). (See figure for breeding, year-round, and nonbreeding ranges of Merlin in the United States and southern Canada.)

Three Merlin subspecies are found in North America (Temple 1972). This account primarily deals with the Richardson's Merlin, F. c. richardsonii, which breeds in the northern Great Plains and prairie parkland. The Black subspecies, F. c. suckleyi, breeds in the dense forested areas of the Pacific Northwest, from western Oregon north to southern Alaska. The Taiga subspecies, F. c. columbarius, breeds in the taiga forests from Maine to northern Canada and Alaska, including the northern Rocky Mountain forest region of Idaho, western Montana, western Wyoming, and western Alberta.

Suitable habitat:

In the Great Plains, Merlins prefer open grasslands for hunting and native or planted tree groves for nesting. They inhabit shortgrass and mixed-grass prairies, tame grasslands, pastures, hayland, shrubsteppe, woodland, wetland, cropland, and urban habitats, especially where these habitats have adjacent riparian woodland (Bent 1961; Fox 1964; Ellis 1976; Hodson 1976, 1978; Oliphant and Thompson 1976; Oliphant and McTaggart 1977; Smith 1978; Houston and Schmidt 1981; Young 1981; Becker 1984; Oliphant and Haug 1985; Becker and Sieg 1988; Dekker 1988; Warkentin and James 1988; Sieg and Becker 1990; Sodhi 1991; Sodhi et al. 1992; Houston and Hodson 1997; MOU 2002). Historically, Merlins inhabited rolling plains that contained small groves of Populus (cottonwoods, aspen) and other deciduous trees that were used for nesting (Bent 1961). During the 1970’s, Richardson’s Merlins began colonizing urban residential and industrial areas in some Canadian cities, most notably Saskatoon (Oliphant 1974, Sodhi et al. 1992) and Regina (Sodhi et al. 1993), Saskatchewan, and Edmonton, Alberta (Smith 1978), following the influx of nesting American Crows (Corvus brachyrhyncos) and Blackbilled Magpies (Pica hudsonia) (Houston and Schmidt 1981), whose old nests are used by Merlins. More recent nesting records were reported in Grand Forks, Minot, Jamestown, and Dickinson, North Dakota (Martin 1999, 2000), and Minneapolis, Minnesota (MOU 2002).

Grasslands are the primary component of Merlin foraging habitat. Merlins require an interspersion of grassland and tree groves to meet the food requirements of pairs and their young (Hodson 1976). Foraging areas are commonly composed of at least 50\% grassland. Merlins prefer native grasslands, probably because native vegetation supports the passerine species upon which Merlins prey (Hodson 1976). The conversion of native grassland to cropland has destroyed much of the traditional Merlin habitat in southwestern Saskatchewan (Hodson 1976). In Alberta, hunting ranges adjacent to 40 nest sites that were occupied during a 6-yr period contained an average of $78 \%$ grassland (Hodson 1976). In southwestern Montana, three radiotagged male Merlins utilized five habitat types: shortgrass prairie, riparian, sagebrush (Artemesia spp.), cropland (grain and fallow fields), hayfields, and ponderosa pine (Pinus ponderosa) woodland (Becker 1984). The majority of radio locations were in sagebrush habitat (53.9\%), followed by grasslands (15.6\%), ponderosa pine (12\%), riparian (9.9\%), and cropland (8.5\%). The three Merlins fed primarily on birds associated with grassland habitat, suggesting that the use of grasslands by Merlins was under-represented by radio-locations, probably because hunting perches were lacking in grasslands.

Wintering areas tend to include open habitats, including open plains and cropland where 
small passerines winter in large flocks; coastal flats and saltwater marshes where sandpipers and other small shorebirds concentrate; or urban areas where House Sparrows (Passer domesticus), Bohemian Waxwings (Bombycilla garrulus), and other small birds are prevalent (Cade 1982). Little is known about winter habitat use in rural parts of the Great Plains because studies have largely focused on urban areas. Merlins spend more time than expected in industrial areas where prey is abundant (Warkentin and Oliphant 1990).

Throughout southern Saskatchewan, Merlin nest sites were located along major river systems (Oliphant and McTaggart 1977). Shelterbelts and groves of deciduous trees on tame grassland also were used by nesting Merlins (Fox 1964). In southeastern Montana, ponderosa pine woodland provided nesting habitat and some hunting habitat, as well as perches and night roosts (Becker 1984). Nest sites usually were located on a south-facing slope in an area with reduced tree density within a short distance of open grassland habitat where Merlins hunted (Becker 1984).

Merlins also nest in cities. Urban habitats in Saskatoon include residential yards, city parks, cemeteries, and university cropland and livestock areas (Oliphant and McTaggart 1977, Sodhi 1991). Male Merlins and some females generally avoided cropland, preferring residential areas, city parks, and grassland habitat both inside and outside of the city during the incubation, nestling, or post-fledging periods (Sodhi 1991). Merlins probably avoided cropland because this habitat had the lowest prey abundance among available habitats. In Edmonton, Merlins utilized river valley and upland nesting habitats (Smith 1978), and they eventually began nesting in white spruce (Picea glauca) planted in the river floodplain after they grew to a height of $\geq 15 \mathrm{~m}$ tall and supported old American Crow nests in their branches. However, only six locations upland from the river valley contained this nesting habitat, mainly in parks and cemeteries (Smith 1978). During one summer, three Merlin pairs nested in Minneapolis, Minnesota, and four active nests were found the following summer (MOU 2002).

As with other falcon (Falco spp.) species, Merlins do not build their own nests. Throughout their range in the northern Great Plains, nearly all nesting pairs use former or unused nests built by American Crows or Black-billed Magpies (Ellis 1976, Hodson 1976, Becker 1984, Warkentin and James 1988, Sieg and Becker 1990, Houston and Hodson 1997). Urban-nesting Merlins often use former crow nests built in spruce (Oliphant and Thompson 1976, Smith 1978, Warkentin and James 1988, Sodhi et al. 1992, MOU 2002). In Grand Forks, North Dakota, two pairs nested in old American Crow nests that were located in spruce (Picea spp.) trees (D. O. Lambeth, Grand Forks, North Dakota, pers. comm.). One nest was located in the yard of a fraternity house, at a busy intersection. In Minot, North Dakota, Merlins nested in a former American Crow nest located about 11m high in a spruce tree in a residential area (R. Martin, Sawyer, North Dakota, pers. comm.).

In rural Saskatchewan and Alberta, old magpie nests were used more often than crow or hawk nests (Fox 1964, Hodson 1976, Houston and Hodson 1997). In Montana, 48 of 49 Merlin pairs used old magpie nests in conifer trees; one pair used a former American Crow nest in a conifer (Ellis 1976, Becker 1984, Sieg and Becker 1990). All 42 former Black-billed Magpie nests used by Merlins had a stick canopy and 60\% had a mud cup in the base (Sieg and Becker 1990). Merlins nesting in other states used old magpie nests built in groves of coniferous trees adjacent to grasslands, including western North Dakota (Stewart 1975, Postovit 1979, Sieg and Becker 1990), western South Dakota (Pulkrabek and O’Brian 1974, Sieg and Becker 1990, SDOU 1991), eastern Wyoming (Sieg and Becker 1990), and northwestern Nebraska (Sieg and Becker 1990, Sharp et al. 2001). 
In Saskatchewan and Alberta, four pairs of Merlins used nests built by hawks. Three of these Merlin pairs used former Swainson's Hawk (Buteo swainsonii) nests (Houston and Schmidt 1981, Houston and Hodson 1997), and one Merlin pair nested in a former Ferruginous Hawk (Buteo regalis) nest (Hodson 1976). Near Calgary, Alberta, three Merlin pairs nested in cavities in the top of broken black poplars (Populus trichocarpa) trees (Bent 1961). In Saskatchewan, two Merlin pairs nested in natural tree cavities (Fox 1964). Although no specific information was provided, Richardson's Merlins were reported to nest occasionally in old magpie nests built in holes in cliffs, and a few Merlins were reported to nest on the ground (Call 1978).

Merlins nest in both coniferous and deciduous trees and shrubs. Coniferous trees supporting nests used by breeding Merlins include ponderosa pine (Bent 1961, Ellis 1976, Becker 1984, Sieg and Becker 1990), spruce (Bent 1961, Fox 1964, Oliphant and Thompson 1976, Smith 1978, Warkentin and James 1988, Sodhi et al. 1992, Houston and Hodson 1997, MOU 2002), jack pine (Pinus banksiana) (Fox 1964), Douglas fir (Pseudotsuga menziesii) (Ellis 1976), and limber pine (Pinus flexilis) (Ellis 1976). Conifers provide easy access and maximum concealment (Becker 1984). Deciduous trees and shrubs that have supported Merlin nests include maple (Acer sp.) (Hodson 1976, Houston and Hodson 1997), box elder (Acer negundo) (Fox 1964), aspen (Bent 1961, Fox 1964, Young 1981, Houston and Hodson 1997), poplar (Bent 1961; Hodson 1976; Oliphant and Thompson 1976, 1978; Smith 1978), black poplar (Bent 1961), cottonwood (Houston and Hodson 1997), birch (Betula sp.) (Fox 1964), green ash (Fraxinus pennsylvanica) (Houston and Hodson 1997), elm (Ulmus sp.) (Houston and Hodson 1997), willow (Bent 1961; Fox 1964; Hodson 1976; Oliphant and Thompson 1976, 1978; Young 1981), and chokecherry (Prunus virginiana) (Houston and Hodson 1997). Nest trees used by 20 pairs of Merlins in Edmonton were at least 35 yr old (Smith 1978). Nest heights among all studies varied from $2 \mathrm{~m}$ in willows (Oliphant and Thompson 1978) to $19 \mathrm{~m}$ in spruce (Warkentin and James 1988). In southeastern Montana, night roosts were located in pine woodlands near nest sites (Becker 1984).

Each member of a Merlin pair uses a favorite perch, often a branch in a tall dead tree that overlooks their territory (Fox 1964). A plucking perch often is used by males to prepare prey before transferring it to the female (Sodhi 1991). Perches also are important for hunting; of 286 hunting attempts, 95\% were initiated from perches (Sodhi et al. 1991b). A table near the end of the account lists the specific habitat characteristics for Merlins by study.

\section{Prey habitat:}

Merlins prey primarily on small birds, usually in open grasslands or sites associated with human habitation (both urban and rural). Merlins may specialize on one or two locally abundant species of small (20- to 40-g) birds (Sodhi et al. 1993). In southwestern Saskatchewan and southeastern Alberta, Horned Larks (Eremophila alpestris), Chestnut-collared Longspurs (Calcarius ornatus), Brown-headed Cowbirds (Molothrus ater), Vesper Sparrows (Pooecetes gramineus), and Song Sparrows (Melospiza melodia) were the most abundant species and the most common prey (Fox 1964; Hodson 1978). In southern Alberta, Merlins hunted for prey primarily over grasslands (Hodson 1978). Grasslands were primarily grazed ( $>75 \%$ of the fields), but some grasslands were hayed and others remained idle. The two most common passerines found in grazed shortgrass prairie were Horned Larks and Chestnut-collared Longspurs, and these two species composed $87 \%$ of the total prey evidence found at Merlin nest sites. In southeastern Montana, 21 species of birds composed the majority of prey taken; seven 
species of prey inhabited woodland and 14 species inhabited grasslands (Becker 1984). During spring and fall, Merlins hunting in pastures and cropland near Beaverhills Lake outside of Edmonton, Alberta, preyed on eight species of sandpipers (Charadriformes) and five species of passerines (Dekker 1988). Rarely, small mammals, lizards, or large insects were utilized as prey, especially by Merlin fledglings.

In urban areas, an abundant prey base (e.g., non-migratory House Sparrows) provides an easily accessible source of food throughout the year (Warkentin and Oliphant 1990, Sodhi 1991). In residential or commercial urban areas, House Sparrows are the most common prey throughout the year, and waxwings (Bombycilla spp.) are important prey during winter (Oliphant and McTaggart 1977, Smith 1978, Servheen 1985, Warkentin and Oliphant 1990, Sodhi 1991). In Saskatchewan, maturation of ornamental mountain ash (Sorbus sp.) and crabapple (Pyrus spp.) trees and the resulting fruit crop attracted more consistent populations of some winter birds, particularly Bohemian Waxwings, making residential areas more attractive for Merlins during winter (Houston and Schmidt 1981).

In Saskatoon, the mean number of birds (potential prey) increased with distance from Merlin nests (Sodhi et al. 1990). During 2 years in which House Sparrow nests were monitored, more sparrow fledglings were available during the Merlin nestling and fledgling periods, when more food (prey) was required by Merlin families (Sodhi et al. 1992). Potential prey species at five point counts in each of four Saskatoon habitats included averages of 4.5 species in urban habitat, 3.7 species in city parks and cemeteries, 2.7 species in grasslands, and 1.5 species in cropland (Sodhi 1991). A second index of abundance of potential prey species indicated that total numbers of individual birds used as prey increased from the Merlin's incubation to nestling period, but decreased markedly during the fledgling period.

\section{Area requirements:}

Breeding Merlins require a large area that provides a nest site and adequate populations of small birds. In Saskatchewan, Merlin home ranges were smaller where prey was more abundant, suggesting that prey abundance is an important variable affecting home range size (Sodhi 1991). The majority of male Merlins in Saskatoon adjusted the size of their range from one breeding period to another (e.g., incubation period to nestling period to fledgling period) in relation to changes in prey abundance. Hunting range size of female Merlins in urban Saskatoon was inversely correlated with their body mass and with House Sparrow abundance. Merlins did not defend hunting ranges for exclusive use, therefore neighbors exerted minimum pressure on hunting range sizes. Some overlap of hunting ranges was documented.

The hunting range sizes of 16 radio-tagged male Merlins and 11 radio-tagged females were studied in Saskatchewan (Sodhi 1991). Of the 16 males, 12 males were defined as residents that were hatched in Saskatoon; four males were defined as immigrants that were hatched at an unknown location outside Saskatoon. The mean hunting range sizes of the 12 resident males averaged $6.3 \mathrm{~km}^{2}$, and the hunting range sizes of the four immigrant males averaged $33.7 \mathrm{~km}^{2}$. The mean hunting ranges of three resident and eight immigrant females averaged $6.6 \mathrm{~km}^{2}$ and $8.6 \mathrm{~km}^{2}$, respectively. Eight of the 12 resident males and all four immigrant males spent some time hunting outside of the city. Seven of eight immigrant females hunted outside of the city compared to only one of three resident females.

In rural Saskatchewan, the minimum distance between breeding pairs along the North Saskatchewan River was 2.5 km (Oliphant and Thompson 1976). In the Kerrobert area of Saskatchewan, the proximity of three neighboring pairs of nesting Merlins was $1.6 \mathrm{~km}$ (Houston 
and Schmidt 1981). In Saskatoon, the distance from a nest site to the nearest adjacent nest site averaged $1.2 \mathrm{~km}$ for 16 nests, ranging from 0.7 to $2.3 \mathrm{~km}$ (Oliphant and Haug 1985). In Edmonton, two pairs of Merlins nested within $1.5 \mathrm{~km}$ of one another in the Saskatchewan River Valley (Smith 1978).

In rural areas, nesting densities were 3.8 pairs $/ 100 \mathrm{~km}^{2}$ in southeastern Montana (Becker and Sieg 1985) and 17.5 pairs/100 km² in southern Alberta (Smith 1978). However, in Edmonton, eight pairs nested in a $40-\mathrm{km}^{2}$ area, suggesting that urban habitat was as attractive, or more attractive, than available rural habitat (Smith 1978). Breeding densities were greater in urban residential, city park, and cemetery habitats than in prairie and cropland habitat. During one breeding season in Saskatoon, 16 Merlin pairs nested within a 29-km² area (Oliphant and Haug 1985). Merlin nesting densities were 25.4 pairs $/ 100 \mathrm{~km}^{2}$ in Saskatoon, Saskatchewan (Sodhi et al. 1992), and 20 pairs of nesting Merlins $/ 100 \mathrm{~km}^{2}$ in Edmonton, Alberta (Smith 1978).

Brown-headed Cowbird brood parasitism:

The Merlin is an unsuitable host for the Brown-headed Cowbird, an obligate brood parasite.

Breeding-season phenology and site fidelity:

On the northern edge of the Great Plains, Merlins are present on breeding territories as early as February, and some may begin courtship activities immediately (Feldsine and Oliphant 1985). Males typically arrive on breeding areas about one month before females. In Alberta, males are common by early April (Bent 1961). In western Saskatchewan, male Merlins arrive in late February or early March (Fox 1964). In southeastern Montana, Merlins arrive about midMarch (Becker 1984, Becker and Sieg 1988). In western Saskatchewan, juvenile Merlins begin migrating southward during mid-August, and the fall flight of migrant Merlins across the Saskatchewan prairies is over by mid-October (Fox 1964). Merlins were one of the last migrants to leave southern Alberta; the latest fall sighting was early December (Bent 1961).

Renesting rarely has been reported for Merlins in the wild; however, apparent renesting has been reported in southern Alberta (Bent 1961, Hodson 1976). Although double-brooding has not been reported for Merlins, polygyny was documented once in Saskatoon (Sodhi 1989). One male occupied two different nest sites that were located about $450 \mathrm{~m}$ apart, and paired with different females at each site. At one nest, four nestlings were successfully raised; the second nest was deserted after about 5 wk after nesting began (from copulation to at least incubation).

In Saskatoon, mate fidelity between breeding seasons was low (20\% of 60 nesting attempts involved the same male and female in two or more consecutive years) and was apparently related to site fidelity (Warkentin et al. 1991). Males were more likely to return to a particular site than females. No changes in productivity were associated with site or mate fidelity. Of 49 territories on which females were trapped, 20\% contained the same birds from one year to the next (James et al. 1989). Of 29 territories on which males were trapped, 41\% contained the same birds from one year to the next. Natal dispersal (movements between birthplace and breeding place) for 15 females was $3.0 \mathrm{~km}$. For 25 males, it was 4.1 +/-2.92 km. These distances reflect movements within the study area, and not longer movements that may have been made outside the study area. A second method of determining natal dispersal was to compare the proportions of male and female adults trapped that had been banded locally as chicks. For females, 39\% of 89 were banded locally as chicks, whereas $60 \%$ of 68 males were 
banded as chicks. Females probably dispersed further than males. Breeding dispersal (movements between two or more breeding places) was $2.3 \mathrm{~km}$ for 29 females, and $1.1 \mathrm{~km}$ for 15 males.

In Alberta, nine of 12 adult male recaptures occurred at the same nest site, two were $<4$ $\mathrm{km}$ from their previous nest sites, and one was $12.8 \mathrm{~km}$ from the original site (Hodson 1976). Of 10 adult female recaptures, two were captured at the same site, three were captured $16-32 \mathrm{~km}$ away, and two were captured $>120 \mathrm{~km}$ away from the original site. Banding-recapture information indicates that pairs re-mate only by chance in ensuing years. It also is likely that most males return to the same site in successive years, whereas most females do not. One ground nest in Newfoundland was used by nesting Merlins (F. c. columbarius) for 23 consecutive years, although it is unknown whether the same pair occupied this site during this period (Trimble 1975).

Species’ response to management:

Murphy (1991) considered Merlins to be one of the prairie raptors that benefits from frequent disturbance of uplands by burning, mowing, or grazing techniques that yield low, lightto-moderately dense grass and forb cover, which forms a habitat mosaic for prey. In Alberta, Merlins hunted over mowed and idle shortgrass prairie (Hodson 1978).

Grazing practices affect the prey species on which Merlins depend and provide open hunting areas for Merlins. In southern Alberta, Merlins hunt for prey primarily over grazed grasslands (Hodson 1978). In southeastern Montana, a combination of low-to-moderate grazing of grassland and sagebrush habitats probably created a diverse mosaic of favorable habitats for the three primary bird species, Horned Larks, Lark Buntings (Calamospiza melanocorys), and Vesper Sparrows, which composed more than half of Merlin prey (Becker 1984). Intensive grazing or the overstocking of livestock may reduce vegetative diversity of grassland and sagebrush habitats, and subsequently reduce prey diversity. In southwestern Saskatchewan, Merlins nested in shelterbelts or in groves of deciduous trees in which the trees had been rubbed bare of the lower branches by cattle and the undergrowth was trampled and destroyed (Fox 1971). These cattle-induced features of trees and shelterbelts appear to be the first stage in the destruction of the trees by cattle.

Conversion of native grasslands into cultivated farmland in rural areas has reduced suitable breeding habitat for Merlins (Trimble 1975), but Merlins have adapted to urban habitats. The breeding range of Richardson's Merlins contracted rapidly during a 20-yr period beginning in 1955. This contraction has been attributed to the conversion of native grasslands to cultivated farmland. Richardson's Merlins that nested in rural Saskatchewan and Alberta shifted their distribution in response to cultivation of prairie. Merlins began to inhabit cities where nest sites and prey were common. Smith (1978) reported that Merlin nesting habitat was created after conifers were planted in the river floodplain in Edmonton, where conifers historically had been scarce. The youngest tree in which an active Merlin nest was found was $35 \mathrm{yr}$ old.

Merlin populations are adversely affected by pesticide contamination that results in eggshell thinning and reduced nesting success. Chemicals causing contamination include DDE (dichlorodiphenylethylene), dieldrin, heptachlor epoxide, PCB (polychorinated biphenyl), and mercury (Ellis 1976, Fyfe et al. 1976, Hodson 1976, Fox and Donald 1980, Becker 1984, Noble and Ellis 1990). The most severe cases of pesticide contamination may go undetected because heavily contaminated Merlins may not attempt to nest or may die without detection (Fyfe et al. 
1976, Fox and Donald 1980, Noble and Ellis 1990). Because Richardson's Merlins winter in the Great Plains of southern Canada, the United States, and northern Mexico, the subspecies does not face continued problems of exposure to persistent pesticides, unlike Taiga Merlins, which winter in Central America and from northern South America to Peru, where persistent pesticides are still used. Due to legislation that prohibited use of persistent pesticides in the United States and Canada, most Merlin populations appear to have recovered from pesticide contamination and are reproducing successfully. However, Merlin eggs collected as recently as 1988 from the prairie provinces in Canada contained pesticide levels high enough to affect reproductive success (Noble and Ellis 1990).

Merlins may be a good indicator species for assessing the impact of environmental disturbances, such as coal mining (Becker and Ball 1983). Merlin populations appear to show less year-to-year fluctuations than raptors that depend on cyclical populations of rodents for food. Merlins obviously can tolerate some human disturbance, because they successfully nest in urban residential areas. Where breeding Merlins already are established and persistent disturbance is subsequently imposed, populations may decline from increased stress and reduced productivity (Becker and Ball 1983). If suitable nesting habitat can be maintained in coalmining recovery areas, Merlins could serve as an indicator of the success of maintenance or recovery efforts of prairie ecosystems. Because Merlin nests often are relatively easy to find, breeding and productivity can be monitored to provide information that is more biologically sensitive than a present-or-absent measurement. Individual Merlins differ in their tolerance to human disturbance. Like other raptors, Merlins are most susceptible to nest abandonment if disturbed during incubation. Nestling survival also may be affected due to prolonged disturbance during brood rearing.

Other human activities also may impact breeding Merlins. Illegal shooting does not appear to be a major mortality factor for Merlins (Fyfe 1977), although shooting probably had a detrimental impact during earlier decades (Evans 1982). However, in Saskatoon, recent shootings caused mortality of $7 \%$ of a Merlin population (James et al. 1989). In southeastern Montana, permanent recreation facilities, such as camping or picnic areas, were likely to displace local nesting pairs of Merlins (Becker 1984). Injury to a Merlin after being caught on a fishhook attached to a discarded fishing line was reported (Parrish and Maurer 1991). Researchers and others that climb nest trees should be careful not to disturb Merlins during early incubation so that the birds desert their nests (Oliphant 1974), because Merlins are most susceptible to nest abandonment if disturbed during incubation than during other periods of their nesting cycle (Becker and Ball 1983). In southeastern Montana, Merlins tolerated repeated nest visits during the brood-rearing period (Becker and Ball 1983).

Radio transmitters that weighed about $2 \%$ of the body mass of an adult Merlin appeared to have no significant effect on reproductive success or survival (Sodhi et al. 1991a). Falconers collect some nestlings or migrating Merlins each year. Falconers must be licensed, but the impacts of falconry on Merlin populations should be monitored continuously. Merlins have bred successfully in captivity, and the release in 1979 of six Merlins in Regina, Saskatchewan, may have been the basis for the establishment of a breeding population that numbered about 20 breeding pairs by around 1992 (Sodhi et al. 1993). 


\section{Management Recommendations:}

Preserve large expanses of grassland and sagebrush-dominated grassland habitats (Becker and Ball 1983). Preserve ponderosa pine stands adjacent to sagebrush and grassland habitats (Becker 1984). Limit human activities in habitats where Merlins are known to nest (Becker 1984). Compensate for destruction, loss, or lack of nest sites by relocating magpie nests into an area, or by constructing artificial nest sites (Becker and Ball 1983).

Encourage rest-rotation grazing plans or similar grazing alternatives that maintain or create a mosaic of livestock grazing areas with a variety of grazing intensities, which should provide a diversity of microhabitats for Merlin prey species (Becker 1984). Do not permit intensive grazing or overstocking of livestock that may reduce vegetative diversity of grassland and sagebrush habitats, and that would likewise reduce Merlin prey abundance.

Continue to restrict the use of pesticides in the United States and Canada (Evans 1982). Because Merlins winter as far south as Peru (Cade 1982), encourage this practice throughout Latin America (Evans 1982).

In areas proposed for mining, begin data collection during the pre-mining phase to gather baseline information about Merlin populations, including data on nesting pairs, productivity, prey utilization, and habitat utilization (Kennedy 1980). Because most studies have utilized data from previous investigations without regard for wide geographic variations in raptor population dynamics and related factors, investigators must conduct long-term, site-specific studies, which will require a much greater commitment of time and funding.

In advance of the exploration and development phases of mining, provide information to workers to help minimize impacts to nesting Merlins, such as access to Merlin habitat by exploration crews, the types of exploration activities proposed, critical periods in the nesting cycle, and guidelines to minimize disturbances (Becker 1984). Prohibit human activities within $400 \mathrm{~m}$ of active nests during the Merlin's breeding season (15 March to 30 July); any exceptions should be examined on a case-by-case basis (Becker and Ball 1983). Where concentrations of nesting pairs occur, initiate more stringent regulations during mining development. Review potential impacts on breeding Merlins and their habitats with regard to the location, timing, and humanuse of the mining facility before roads or industrial facilities are developed. Require that all personnel adhere to guidelines on location, scheduling, and zones of disturbance (Becker 1984).

Emphasize the protection of natural nest sites, habitats, and populations during the development phase of mining or during mining activities, when Merlin nesting and hunting habitats are likely to be seriously disturbed or destroyed (Becker and Ball 1983). Protect mature trees whenever possible, because it may take several decades to re-establish nesting, perching, and roosting trees. Restrict firearms on mining sites to deter illegal shooting of Merlins.

During the reclamation phase of mining, re-establish diverse native vegetation as rapidly as possible after mining activities cease (Becker 1984). Replace nest trees with the largest possible trees by transplanting. If grazing is permitted, protect existing or transplanted trees from damage 
by livestock by fencing. In areas where human activities impact Merlin nesting territories, establish a 400-m radius zone of no disturbance surrounding known or suspected nest sites from 15 March to 30 July.

Locate permanent recreation facilities away from known or potential Merlin nest sites (Becker 1984). Review potential impacts on breeding Merlins and their habitats before developing recreation areas and associated roads with regard to the location of facilities, timing of disturbances, and human uses of any facilities (Trimble 1975, Becker 1984). Carefully regulate falconry to ensure that Merlin populations are not impacted locally, regionally, or rangewide (Trimble 1975). 
Table. Merlin habitat characteristics.

\begin{tabular}{|c|c|c|c|}
\hline Author(s) & Location(s) & Habitat(s) Studied* & Species-specific Habitat Characteristics \\
\hline $\begin{array}{l}\text { Becker 1984, } \\
\text { Becker and Sieg } 1988\end{array}$ & Montana & $\begin{array}{l}\text { Cropland, mixed-grass } \\
\text { pasture, riparian } \\
\text { woodland, } \\
\text { shrubsteppe, } \\
\text { woodland }\end{array}$ & $\begin{array}{l}\text { Nested in former Black-billed Magpie (Pica hudsonia) nests } \\
\text { built in ponderosa pine (Pinus ponderosa); hunted and perched } \\
\text { in shrubsteppe (Artemesia spp.), mixed-grass prairie, } \\
\text { ponderosa pine woodland, riparian, and cropland; preyed } \\
\text { primarily on birds associated with prairie habitat }\end{array}$ \\
\hline Bent 1961 & Alberta & $\begin{array}{l}\text { Shortgrass prairie, } \\
\text { woodland }\end{array}$ & $\begin{array}{l}\text { Nested in cavities in the tops of broken black poplars (Populus } \\
\text { trichocarpa), in dense spruce (Picea sp.) woods, in poplars } \\
\text { (Populus spp.) in small groves, and in an old, canopied Black- } \\
\text { billed Magpie nest in a willow (Salix sp.) stand; nests ranged } \\
\text { in height from } 4.5 \text { to } 18 \mathrm{~m} \text { above the ground }\end{array}$ \\
\hline Dekker 1988 & Alberta & $\begin{array}{l}\text { Cropland, } \\
\text { shortgrass pasture }\end{array}$ & Hunted in cropland and shortgrass pasture \\
\hline Ellis 1976 & Montana & $\begin{array}{l}\text { Cropland, } \\
\text { shortgrass prairie, } \\
\text { woodland }\end{array}$ & $\begin{array}{l}\text { Of seven nests, six were in magpie nests in Douglas fir } \\
\text { (Pseudotsuga menziesii), ponderosa pine (Pinus ponderosa), } \\
\text { limber pine (Pinus flexilis), and one unidentified conifer; the } \\
\text { remaining nest was in a former American Crow (Corvus } \\
\text { brachyrhynchos) nest in a ponderosa pine; prairie habitat } \\
\text { adjacent to nest sites included flat or rolling landscapes, } \\
\text { although three nest sites were located on hills above prairie; } \\
\text { nest sites were located in four conifer groves bordering open } \\
\text { prairie, a conifer grove on a butte above open prairie and } \\
\text { cropland, a small dense conifer grove in a mesic draw, and a } \\
\text { conifer shelterbelt near a highway surrounded by prairie }\end{array}$ \\
\hline Fox 1964 & Saskatchewan & $\begin{array}{l}\text { Mixed-grass pasture, } \\
\text { riparian, tame pasture, } \\
\text { woodland }\end{array}$ & $\begin{array}{l}\text { Of } 25 \text { nests, } 12 \text { were in woodland, on bluffs, river edges or } \\
\text { islands; seven were in shelterbelts among open grassland, and } \\
\text { six were in coniferous woodland; } 21 \text { nests were in deciduous } \\
\text { trees, and four were in coniferous trees; } 13 \text { nests were } \\
\text { originally built by crows, } 10 \text { were built by magpies, and two } \\
\text { were in natural tree cavities }\end{array}$ \\
\hline
\end{tabular}




\begin{tabular}{|c|c|c|c|}
\hline Hodson 1976 & $\begin{array}{l}\text { Alberta, } \\
\text { Saskatchewan }\end{array}$ & $\begin{array}{l}\text { Cropland, mixed-grass } \\
\text { pasture, shortgrass } \\
\text { pasture }\end{array}$ & $\begin{array}{l}\text { Hunting ranges adjoining } 40 \text { nest sites averaged } 78 \% \text { grassland } \\
\text { and } 22 \% \text { cropland and woodland; grasslands were primarily } \\
\text { mixed-grass prairie dominated by needlegrass (Stipa) and } \\
\text { wheatgrass (Agropyron) or shortgrass prairie dominated by } \\
\text { grama (Bouteloua) and needlegrass (Stipa), but their } \\
\text { composition was dependent on grazing pressure; in heavily } \\
\text { grazed grassland, fringed sagewort (Artemesia frigida) and } \\
\text { needleleaf sedge (Carex duriuscula) were common; trees in } \\
\text { grasslands occurred in natural groves of quaking aspen } \\
\text { (Populus tremuloides) and willows (Salix sp.) that surrounded } \\
\text { wetlands, and in stands of aspen, willow, and box elder (Acer } \\
\text { negundo), which were remnants of planted windbreaks; most } \\
\text { pairs nested in former magpie and crow nests, but one pair } \\
\text { nested in a former Ferruginous Hawk (Buteo regalis) nest; } \\
\text { prime factors affecting the Merlin population were human- } \\
\text { induced land-use changes, especially conversion of native } \\
\text { grasslands to cropland }\end{array}$ \\
\hline Hodson 1978 & Alberta & $\begin{array}{l}\text { Idle shortgrass, } \\
\text { shortgrass hayland, } \\
\text { shortgrass pasture, } \\
\text { woodland }\end{array}$ & $\begin{array}{l}\text { Nested in small native or planted groves of poplars (Populus } \\
\text { sp.), willows, and/or box elder adjacent to shortgrass } \\
\text { (Stipa/Agropyron) prairie; primarily hunted for prey over } \\
\text { shortgrass prairie, which was mostly grazed, but included } \\
\text { some mowed shortgrass hayland and idle shortgrass }\end{array}$ \\
\hline $\begin{array}{l}\text { Hodson and Hodson } \\
1997\end{array}$ & Saskatchewan & Not given & $\begin{array}{l}\text { Of } 125 \text { Merlin nests, } 102 \text { originally were built by magpies, } 21 \\
\text { by crows, and two by Swainson's Hawks; most Merlin nests } \\
\text { were in deciduous trees; } 66 \text { nests were in maple (Acer sp.), } 22 \\
\text { in aspen, } 13 \text { in green ash (Fraxinus americana), } 11 \text { in willow, } \\
5 \text { in elm (Ulmus sp.), } 3 \text { in unidentified trees, } 2 \text { in cottonwood, } \\
2 \text { in spruce, and } 1 \text { in chokecherry (Prunus virginiana) }\end{array}$ \\
\hline $\begin{array}{l}\text { Houston and Schmidt } \\
1981\end{array}$ & Saskatchewan & $\begin{array}{l}\text { Riparian woodland, } \\
\text { urban }\end{array}$ & $\begin{array}{l}\text { Early records indicate nesting Merlins were restricted to } \\
\text { wooded river valleys; most nests were former magpie and } \\
\text { crow nests; however, one pair of Merlins used a former } \\
\text { Swainson’s Hawk (Buteo swainsonii) nest; maturation of }\end{array}$ \\
\hline
\end{tabular}




\begin{tabular}{|c|c|c|c|}
\hline & & & $\begin{array}{l}\text { ornamental mountain ash (Sorbus sp.) and crabapple (Pyrus } \\
\text { sp.) trees attracted more consistent populations of winter birds, } \\
\text { particularly Bohemian Waxwings (Bombycilla garrulus), } \\
\text { making residential areas more attractive for Merlins during } \\
\text { winter }\end{array}$ \\
\hline $\begin{array}{l}\text { D. O. Lambeth, Grand } \\
\text { Forks, North Dakota } \\
\text { pers. comm. }\end{array}$ & North Dakota & Urban & $\begin{array}{l}\text { Two pairs nested in old crow nests in spruce trees in Grand } \\
\text { Forks; one nest was located in the yard of a fraternity house at } \\
\text { a busy intersection }\end{array}$ \\
\hline MOU 2002 & Minnesota & Urban & $\begin{array}{l}\text { One pair nested successfully in a tall spruce tree in a suburb of } \\
\text { Minneapolis }\end{array}$ \\
\hline Oliphant and Haug 1985 & Saskatchewan & Urban & Nested primarily in old crow nests built in mature spruce trees \\
\hline $\begin{array}{l}\text { Oliphant and McTaggart } \\
1977\end{array}$ & Saskatchewan & $\begin{array}{l}\text { Cropland, pasture, } \\
\text { urban }\end{array}$ & $\begin{array}{l}\text { One nest site was on a university campus; the male hunted in } \\
\text { adjacent residential areas and the university’s cropland and } \\
\text { livestock areas; a second nest site was in a tree in a city } \\
\text { cemetery; that male hunted in the cemetery and in adjacent } \\
\text { residential and semi-industrial areas }\end{array}$ \\
\hline $\begin{array}{l}\text { Oliphant and Thompson } \\
1976\end{array}$ & Saskatchewan & $\begin{array}{l}\text { Riparian woodland, } \\
\text { urban }\end{array}$ & $\begin{array}{l}\text { Throughout southern Saskatchewan, nests were located along } \\
\text { major river systems; along a 40-km stretch of the North } \\
\text { Saskatchewan River near Saskatoon, most Merlins nested in } \\
\text { unused crow or magpie nests in small willows 2- to 4-m high, } \\
\text { or in old magpie nests in large deciduous trees, usually } \\
\text { Populus species; in areas of Saskatoon, Merlins nested } \\
\text { primarily in old crow nests built in mature spruce trees }\end{array}$ \\
\hline Sieg and Becker 1990 & Montana & $\begin{array}{l}\text { Cropland, mixed-grass } \\
\text { pasture, shortgrass } \\
\text { pasture, woodland }\end{array}$ & $\begin{array}{l}\text { Preferred nesting in unused magpie nests in ponderosa pines } \\
\text { on south-facing slopes of sandstone buttes that ranged about } \\
300 \mathrm{~m} \text { above adjacent grazed prairies that were dominated by } \\
\text { western wheatgrass (Agropyron smithii), blue grama } \\
\text { (Bouteloua gracilis), prairie junegrass (Koeleria cristata), and } \\
\text { needle-and-thread grass (Stipa comata) }\end{array}$ \\
\hline Smith 1978 & Alberta & Urban, woodland & $\begin{array}{l}\text { Nested in unused corvid nests ( } 11 \text { crow and } 3 \text { magpie nests) } \\
\text { located in } 13 \text { spruce trees and one aspen; all trees were at least }\end{array}$ \\
\hline
\end{tabular}




\begin{tabular}{|l|l|l|l|}
\hline & & & $\begin{array}{l}35 \text { yr old; in an urban area, 9 pairs nested in the river valley } \\
\text { and 5 pairs nested in upland city parks or cemeteries; in rural } \\
\text { areas, 17 of 18 nests were in spruce }\end{array}$ \\
\hline $\begin{array}{l}\text { Sodhi 1991; } \\
\text { Sodhi et al. 1990, }\end{array}$ & Saskatchewan & $\begin{array}{l}\text { Cropland, mixed-grass } \\
\text { pasture, tame pasture, } \\
\text { urban }\end{array}$ & $\begin{array}{l}\text { Nested in crow nests built in mature spruce trees; a high } \\
\text { reproductive rate indicated the urban environment provided } \\
\text { prime habitat with ample corvid nest sites in spruce trees and } \\
\text { abundant prey, primarily House Sparrows (Passer domesticus); } \\
\text { hunted in urban habitat, and grasslands and croplands adjacent } \\
\text { to the city }\end{array}$ \\
\hline $\begin{array}{l}\text { Warkentin and James } \\
1988\end{array}$ & Saskatchewan & $\begin{array}{l}\text { Urban } \\
\text { tendency to avoid nesting in magpie nests; used crow nests } \\
\text { during 54 of 58 nesting attempts; average nest site } \\
\text { characteristics at 58 active Merlin nests were 12.5 m nest tree } \\
\text { height, 40.6 cm nest tree diameter, 8.9 m nest height, 1.9\% } \\
\text { shrub coverage, 57.2 m distance from nest tree to nearest } \\
\text { building, 22.4 m distance to nearest road, and 35.6 m distance } \\
\text { to nearest light pole. }\end{array}$ \\
\hline Young 1981 & $\begin{array}{l}\text { One pair nested in an old magpie nest built 3 m above ground } \\
\text { in a stunted aspen on a bluff overlooking an 11-km-long } \\
\text { glacial outwash valley devoid of trees except along spring-fed } \\
\text { ravines and north-facing slopes; a second pair nested in an old } \\
\text { magpie nest built 3.7 m above the ground in a 0.5-km² aspen- } \\
\text { and-willow thicket in an area composed of stunted trees, } \\
\text { including aspens and willows, and sagebrush }\end{array}$ \\
\hline
\end{tabular}

*In an effort to standardize terminology among studies, various descriptors were used to denote the management or type of habitat. "Idle" used as a modifier (e.g., idle tallgrass) denotes undisturbed or unmanaged (e.g., not burned, mowed, or grazed) areas. "Idle" by itself denotes unmanaged areas in which the plant species were not mentioned. Examples of "idle" habitats include weedy or fallow areas (e.g., oldfields), fencerows, grassed waterways, terraces, ditches, and road rights-of-way. "Tame" denotes introduced plant species (e.g., smooth brome [Bromus inermis]) that are not native to North American prairies. "Hayland" refers to any habitat that was mowed, regardless of whether the resulting cut vegetation was removed. "Burned" includes habitats that were burned

intentionally or accidentally or those burned by natural forces (e.g., lightning). In situations where there are two or more descriptors (e.g., idle tame hayland), the first descriptor modifies the following descriptors. For example, idle tame hayland is habitat that is usually mowed annually but happened to be undisturbed during the year of the study. 


\section{LITERATURE CITED}

Becker, D. M. 1984. Reproductive ecology and habitat utilization of Richardson's Merlins in southeastern Montana. M.S. thesis. University of Montana, Bozeman, Montana. 86 pages.

Becker, D. M., and I. J. Ball. 1983. Merlin (Falco columbarius). Pages 124-137 in J. S. Armbruster, editor. Impacts of coal surface mining on 25 migratory bird species of high federal interest. U.S. Fish and Wildlife Service FWS/OBS-83/35.

Becker, D. M., and C. H. Sieg. 1988. Breeding chronology and reproductive success of Richardson's Merlins in southeastern Montana. Canadian Journal of Zoology 66:925928.

Bent, A. C. 1961. Life histories of North American birds of prey. Part 2. Dover Publications, New York, New York. 482 pages.

Brown, L., and D. Amadon. 1968. Merlin. Eagles, hawks, and falcons of the world. Volume 2. Country Life Books, Hamlyn Publishing Group, Feltham, Middlesex. 945 pages.

Buchanan, J. B. 1988. The effect of kleptoparasitic pressure on hunting behavior and performance of host Merlins. Journal of Raptor Research 22:63-64.

Cade, T. 1982. Merlin. Pages 112-116 in The falcons of the world. Cornell University Press, Ithaca, New York. 188 pages.

Call, M. W. 1978. Nesting habits and surveying techniques for common western raptors. U.S. Department of the Interior, Bureau of Land Management Technical Note TN-316. Denver Service Center, Denver, Colorado. 115 pages.

Dekker, D. 1988. Peregrine Falcon and Merlin predation on small shorebirds and passerines in Alberta. Canadian Journal of Zoology 66:925-928.

Ellis, D. H. 1976. First breeding records of Merlins in Montana. Condor 78:112-114.

Evans, D. L. 1982. Merlin (Falco columbarius). Status reports on 12 raptors. U.S. Fish and Wildlife Service Special Scientific Report, Wildlife Number 238. Washington, D.C. 68 pages.

Feldsine, J. W., and L. W. Oliphant. 1985. Breeding behavior of the Merlin: the courtship period. Raptor Research 19:60-67.

Fox, G. A. 1964. Notes on the western race of the Pigeon Hawk. Blue Jay 22:140-147.

Fox, G. A. 1971. Recent changes in the reproductive success of the Pigeon Hawk. Journal of 
Wildlife Management 35:122-128.

Fox, G. A., and T. Donald. 1980. Organochlorine pollutants, nest-defense behavior and reproductive success in Merlins. Condor 82:81-84.

Fyfe, R. W., R. W. Risebrough, and W. Walker, II. 1976. Pollutant effects on the reproduction of the Prairie Falcons and Merlins of the Canadian prairies. Canadian Field-Naturalist 90:346-355.

Godfrey, W. E. 1970. Canada’s endangered birds. Canadian Field-Naturalist 84:24-26.

Hodson, K. A. 1976. The ecology of Richardson's Merlins on the Canadian prairies. M.S. thesis. University of British Columbia, Vancouver, British Columbia. 83 pages.

Hodson, K. 1978. Prey utilized by Merlins nesting in shortgrass prairies of southern Alberta. Canadian Field-Naturalist 92:76-77.

Houston, C. S., and K. A. Hodson. 1997. Resurgence of breeding Merlins, Falco columbarius richardsonii, in Saskatchewan grasslands. Canadian Field-Naturalist 111:243-248.

Houston, C. S., and A. Schmidt. 1981. History of Richardson’s Merlin in Saskatchewan. Blue Jay 39:30-37.

James, P. C., and L. W. Oliphant. 1986. Extra birds and helpers at the nests of Richardson's Merlin. Condor 88:533-534.

James, P. C., I. G. Warkentin, and L. W. Oliphant. 1989. Turnover and dispersal in urban Merlins. Ibis 131:426-429.

Kennedy, P. L. 1980. Raptor baseline studies in energy development. Wildlife Society Bulletin 8:129-135.

Lieske, D. J., L. W. Oliphant, P. C. James, I. G. Warkentin, and R. H. M. Espie. 1997. Age of first breeding in Merlins (Falco columbarius). Auk 114:288-290.

Lieske, D. J., I. G. Warkentin, P. C. James, L. W. Oliphant, and R. H. M. Espie. 2000. Effects of population density on survival in Merlins. Auk 117:184-193.

Minnesota Ornithologists' Union (MOU). 2002. Metro Merlins are a surprise. Minnesota Birding 39:14.

Murphy, R. K. 1991. Ecology and management of prairie raptors. Proceedings of the nongame wildlife workshop. U.S. Fish and Wildlife Service, Region 6. 10 pages. 
National Geographic Society. 1999. Field guide to the birds of North America, third edition. National Geographic Society, Washington, D.C. 480 pages.

Noble, D. G., and J. E. Ellis. 1990. Levels of contaminants in Canadian raptors, 1966 to 1988: effects and temporal trends. Canadian Field-Naturalist 104:222-243.

Oliphant, L. W. 1974. Merlins - the Saskatoon falcons. Blue Jay 32:140-147.

Oliphant, L. W., and E. Haug. 1985. Productivity, population density and rate of increase of an expanding Merlin population. Raptor Research 19:56-59.

Oliphant, L. W., and S. McTaggart. 1977. Prey utilized by urban Merlins. Canadian FieldNaturalist 91:190-192.

Oliphant, L. W., and W. J. P. Thompson. 1976. Food caching behavior in Richardson’s Merlin. Canadian Field-Naturalist 90:364-365.

Oliphant, L. W., and W. J. P. Thompson. 1978. Recent changes in the reproductive success of the Pigeon Hawk. Raptor Research 12:35-39.

Parrish, J. R., and B. A. Maurer. 1991. Injury to a Merlin (Falco columbarius) from discarded fishing tackle. Journal of Raptor Research 25:136-139.

Postovit, H. R. 1979. Population estimates of breeding raptors in the North Dakota Badlands. M.S. thesis. North Dakota State University, Fargo, North Dakota. 50 pages.

Pulkrabek, M., and D. O’Brian. 1974. An inventory of raptor nesting in Harding County, South Dakota - 1974. Pittman-Robertson Project W-95-R-8. South Dakota Department of Game, Fish and Parks report. Pierre, South Dakota. 5 pages.

Servheen, C. 1985. Notes on wintering Merlins in western Montana. Raptor Research 19:97-99.

Sharpe, R. S., W. R. Silcock, and J. G. Jorgensen. 2001. Birds of Nebraska, their distribution and temporal occurrence. University of Nebraska Press, Lincoln, Nebraska. 520 pages.

Sieg, C. H., and D. M. Becker. 1990. Nest-site habitat selected by Merlins in southeastern Montana. Condor 92:688-694.

Smith, A. R. 1978. The Merlins of Edmonton. Alberta Naturalist 8:188-191.

Sodhi, N. S. 1989. Attempted polygyny by a Merlin. Wilson Bulletin 10:506-507.

Sodhi, N. S. 1991. Foraging ecology of urban-breeding Merlins (Falco columbarius). Ph.D. dissertation. University of Saskatchewan, Saskatoon, Saskatchewan. 133 pages. 
Sodhi, N. S., A. Didiuk, and L. W. Oliphant. 1990. Differences in bird abundance in relation to proximity of Merlin nests. Canadian Journal of Zoology 68:852-854.

Sodhi, N. S., P. C. James, I. G. Warkentin, and L. W. Oliphant. 1992. Breeding ecology of urban Merlins (Falco columbarius). Canadian Journal of Zoology 70:1477-1483.

Sodhi, N. S., L. W. Oliphant, P. C. James, and I. G. Warkentin 1993. Merlin (Falco columbarius). A. Poole and F. Gill, editors. The birds of North America, No. 44. Academy of Natural Sciences, Philadelphia, Pennsylvania; American Ornithologists' Union, Washington, D.C.

Sodhi, N. S., I. G. Warkentin, P. C. James, and L. W. Oliphant. 1991a. Effects of radiotagging on breeding Merlins. Journal of Wildlife Management 55:613-616.

Sodhi, N. S., I. G. Warkentin, and L. W. Oliphant. 1991b. Hunting techniques and success rates of urban Merlins (Falco columbarius). Journal of Raptor Research 25:127-131.

South Dakota Ornithologists' Union (SDOU). 1991. The birds of South Dakota, second edition. South Dakota Ornithologists’ Union, Aberdeen, South Dakota. 311 pages.

Stewart, R. E. 1975. Breeding birds of North Dakota. Tri-College Center for Environmental Studies, Fargo, North Dakota. 295 pages.

Temple, S. A. 1972. Systematics and evolution of the North American Merlins. Auk 89:325338.

Trimble, S. A. 1975. Merlin (Falco columbarius). Habitat management series for unique or endangered species. Report Number 15. U.S. Department of the Interior. Bureau of Land Management Technical Note T-N-271, Denver, Colorado. 41 pages.

Warkentin, I. G., and P. C. James. 1988. Nest-site selection by urban Merlins. Condor 90:734738.

Warkentin, I. G., P. C. James, and L. W. Oliphant. 1991. Influence of site fidelity on mate switching in urban-breeding Merlins (Falco columbarius). Auk 108:294-302.

Warkentin, I. G., and L. W. Oliphant. 1990. Habitat use and foraging behaviour of urban Merlins (Falco columbarius) in winter. Journal of Zoology 221:539-563.

Young, A. G. 1981. Observations of the Merlin from Unity, Saskatchewan. Blue Jay 39:38-40. 